\title{
Is community forestry of Nepal's Terai in right direction?
}

\author{
Jagadish Chandra Baral ${ }^{1}$ and Bodh Raj Subedi ${ }^{2}$
}

\begin{abstract}
The paper which is based on the study visit of twenty districts of the Terai has attempted to describe some descrepancies of community forestry in the region. Although, it is argued that the trend of forest degradation has decreased since handover, but at the same time a number of unintended social anomalies have also arised. Such anomalies essentially constitute of inequity and unfairness in the local and national level and in terms of long-term sustainability of forest resources. To minimise such irregularites a steady and 'process oriented' handover is suggested instead of those based on inadequate field works.
\end{abstract}

Keywords: Community forestry, Terai, Nepal

\begin{abstract}
ince inception, the community forestry in the $\checkmark$ Terai has drawn controversy in some form or other. Questions have also been raised whether or not this form of forest management which emerged from the experiences gained from hills, is suitable in the Terai. Differences in opinion amongst the country's forestry professionals prevail. The Forest Act (HMG, 1993) and Forest By-law (HMG, 1995) have stipulated the provision of handing over but, the forestry policy (1989) is not very precise in this particular matter. Nonetheless, large tracts of commercially important forests are being handed over without having an explicit idea on its destiny. In such predicament, the present paper attempts to depict the existing issues prevailing in the community forestry in the Terai so that the informed people of the country could have better understinding of the present form of community forestry in the Terai.
\end{abstract}

The findings of the paper is based on direct observation of the fields; informal interviews with the executive members of the various community forestry user groups and government forestry professionals of the twenty districts of the Terai (viz.)

While there is a conspicuous degree of positive change in forest condition after handover, but several practical and social anomalies also prevail. It was found that forests are being conserved ever since the official handovers. The elite members in particular, who often occupy the executive positions, tend to put restrictions in the forest use thus causing protection or rejuvenation of the resource. It was amazing that several degraded areas have been converted into green forests which were otherwise degraded bush lands. The Siwalik of Siraha, Saptari, Udyapur and Dhanusha districts are examples of such alterations. While one can hardly deny the efficacy of the local protection regime, the social anomalies regarding the handover are conspicuous. We intend to deal few such issues in brief.

\section{Issues}

'Land grab' issue

At many places, the House holds (HHs) situated near rich forests have shown a tendency to claim a large tract of forests, not even thinking properly whether they can actually manage such areas. The Chhatiwan community forest of Kaliali District is a burning example of this kind. Four thousands hectares of dense sal-sisoo-khair (Shorea robusta - Dalbergia sissoo and Acacia catachu) forest has been officially handed over to merely 1,600 $\mathrm{HHs}$, majority of which are newely migrated to Kailali from Achham, a hill district. Such shift has affected the use rights of a large number of Tharu ethnic communities of Rajapur (Bardiya District) across Karnali River. Only the ones who were located close to the bank had a luck of being incorporated into the group owing to their perceived protection potential. As many as eleven Village Development Committees from this area had been intensively using this forest in the past because their area has virtually no forests. They did use the forest when current of the mighty river calmed down in the post monsoon period. A serious blow on their traditional use rights meant that they are at present fighting a case with the official user groups, but have little hope to win. This is firstly because they are the

\footnotetext{
${ }^{12} \&$ Department of Forest, Kathmandu
} 


\section{Banko Janakari, Vol. 9, No. 2}

weaker ethnic community and secondly because the District Forest Office (DFO) has already formalised the handover. They need to fight a battle not only with the official group but also with the DFO, a government entity. Federation of Communitity Forestry User Groups Nepal (FECOFUN) though has shown some degree of concern about the equity issue within the recognised groups, they are understood to limit their consern within them and do not wish to persue an issue where there is a total loss of use right - an issue which is even more serious.

In Jhapa District more than fifty percent of the tota forest area has been handed over to communities. The rest too are in the control of local people and seems ready to be handed over as community forests for being pressurised by the FECOFUN. What is unfortunately evident is that, all those who depend upon these resources since long have not been involved so far. The ethnic Rajbamsi who are situated at some distance from the forests seem to be the most sufferer.

\section{Non transparency}

The normal trend in community forestry has shown us that the elite members of the society tend to take all positions of the executive committee, and make decisions regarding harvest, product distribution and mobilisation of fund accrued. The other (ordinary) members of the group are least involved in the overall process and have virtually no idea whatsoever related to harvest, and the financial matters of their community forest.

The executives in Chhatiwan community forest have imposed several ban against collection of forest products to the user group members and that most of the products are sold to the contractors. Even the period of selling some timber at a subsidised rate does not allegedly suited to the user group members. The period is such that, the members are in hardship because of their investment in agriculture and/or they have to pay the annual fees of their children. These indicated poor involvement of the ordinary users in decision making.

The Forest User Committee (FUC) records show that 27000 cubic feet of timber and substantial quantity of other products such as honey, Sikakai and fish have been collected by the group which is equivalent to more than ten million rupees. However, a building is under construction, but, it is indeed amazing to note that the group has a balance of only rupees seven thousand in their account. When asked about the detail where rest of the money had been spent, the committee members
Baral \& Subedi

could not answer satisfactorily. They have not maintained their monetary records for last six months as they say that they were too busy to do so. While, rest of the people in the group do not believe that the amount has been used properly, but, they were too hesitant to make any inquiry.

The Hachumasa Community Forest User Group in Jhapa District had taken an exceptional decision of exchanging a substantial quantity of timber for a powerful tractor. In this case, amazingly, not even other members of the executive committee knew about it. The 'major five' - the Chairman, vice- chairman, secretary, joint secretary and the treasurer tend to take all vital decisions.

These are few examples that typically indicate the misconduct in Nepal's Terai community forestry, to which neither the government nor the responsible agencies such as (FECOFUN) have answer.

\section{Forests in the hands of encroachers}

The Rudrapur Community Forest User Group (FUG) of Rupandehi District was found to be handed over to illegal settlers. While trying to dig out the underlying reasons for the handover a strange picture appeared. It was learnt that the DFO tried hard to evict the illegal settlers. He, instead found the encroachment rate increasing, and in his desperation, he decided to handover forests to the same group of encroachers thinking that further encroachment would be halted. And he was right as the newly formed executive committee put restriction into the forest to allow regeneration. But it may be noted that the supposedly lawbreacher were not only supported by giving a consent to live on but also that they were handed over with vast amount of rich forest. This obviously has a serious philosophical implication. Besides, the act is sure to set a precedence that would help encouraging similar encroachments elsewhere.

\section{Implication for the government treasury}

Forestry sector's contribution to the national treasury has been progressively dropped for the last three years. These periods correspond eith the time since forest handover has taken a momuentum particularly in the Terai. The Department of Forest's sources has shown that the sell of products like timber, fuelwood, herb, etc. has accounted for over 335.4 million rupees in the year 1995/96 (Nepali fiscal year 052/053). In the subsiquent years this figure dropped down to around 31906 million in '96/97 and 242.7 milion in ' $97 / 98$. While there may be more than one reason for such decline, handing over of community forestry seems clearly one of them. With the progression of hand over, 
contribution of forestry sector to the national treasury will obviously decrease. One can of course, argue that the local people can take development initiatives on their own out of the generated funds which will compensate the government's future liability to conduct developmet progammes in the areas. But, the lack of tansperancy in account keeping system allows the limited groups of elite a pretty good chance to reap benefit out of the system. This can be either by way of fiddling the accounts or by carrying out the development activities that serves their vested interest than that of the general people. The case of Chhatiwan is an example to this. There is one other point to consider. Even if one transparency can be achieved, a stark concern that would still remain, is that can the nation entrust resources to a group of people only ? It may be noted particularly in the context of the Terai that many of the people who are located near the huge tract of forest lands are the migrants from the hills. They have advertently or inadvertently displaced the ethnic groups of people who now have settled in a place far away from the forests. The open question that can the government entrust the resource and the resulting income to someone who happened to be located near the forest patches by fluke? Does the act of handing over such resource to these people do a justice to others who have not had a chance to settle in an area next to such huge resources? The analogue is some thing such as allowing a group of households situated near the Tribhuwan International Airport in Kathmandu to collect duty on all the imports? They would, of course, be a good alternative to the prevailing government system of duty collection if looked from the viewpoint of effectiveness. However, this alternative will have to be rejected plainly because the fund raised from the duty has a much more liability than developing the areas around the airport. It has to serve the nation as a whole by way of being a source of fund for the headings like paying salary to civil servants or for constructing a primary school at the most remote areas of the country. It is therefore, the rich forests of the Terai is expected to serve not only those who are next the resource but to the nation as a whole. This is the crux the stakeholders should always bear in mind.

\section{Shift of pressure to public forests}

As soon as any forest area is handed over to a community, the first reaction the local community shows is to protect 'their' community forest. While doing so the pressure of harvesting forestry products is normally diverted to the adjacent public forest. The Churia forest north of Dhalkebar bazaar of Dhanusha District is its typical example.
Immediately after handing over as community forest, the elite members of the user committee put a ban against the use of forest products. Consequently, the local users started harvesting the state forest with such an intensity that it culminated the exchange of firing between the District Forest Office and the local citizen.

Carrying away green wood, poles and other forestry products from government forests is a common sight everywhere, and subsequently the state forest is depleting elsewhere. Proper thought should have been there to save the state forest while increasing the productivity of the community forests.

\section{Sustainability in question}

As already stated, after handing over, protection of forests starts immediately. In most of the cases, it is through coercion than through the willing participation of the general users. The committee deputes watchers who are paid from the fund available by selling forest produce. This is contrasting to the hill situation where people normally voluenteer to watch their forest.

In the case of Chhatiwan community forest, the miniscule amount of rupees seven thousand is not enough to pay the eighteen employed watcher even for a month. The only way for them to continue the watching arrangement is to collect more money so as to pay for the watchers. In the lack of other alternatives, the committee has no option but to do more intensive harvesting to pay watchers, which seems not sustainable in the long run. Several FUGs in Dang District have been selling their valuable khair at an unimaginably low rate. They are selling the product to the contractors at around rupees two per $\mathrm{kg}$ whereas the minimum rate fixed by the government is rupees ten and that the market price stands at around rupees fifteen. Whatever amount have been accrued from the sale of such products had already been spent in some way or other. This clearly indicates that a long term sustainability $i_{s}$ questionable irrespective of the fact that the protection regime at the moment is reasonably effective for maintaining the greenery.

This is a simple example that shows the long term sustainabilty is in question.

\section{Discussions}

Community forestry in the Terai in its present form seems problematic from social and the humanitarian viewpoint. Loss of use rights due to the land grabbing by more influential group; the lack of 
Banko Janakari, Vol. 9, No. 2

transparency within the groups, etc. are amongst the most sentimental problems existing at present. While these situation may apply everywhere in the country, it is more serious in the Terai where the hill migrants have normally settled near the rich patches of forest, and tend to manipulate the situation for their benefit.

At a general glance, forest degradation may seem to have been controlled at present, there is, however no guarantee in the future essentially because of the coercive principle rather than on general consensus (see also Gronow and Shrestha (1990) and Fisher et. al. (1989). The employment of paid watchers does not seem sustainable simply because the committee people may not be able to employ watcher any longer after the fund ceases, and that people are not ready to co-operate.

It may be pointed out that we do not have enough experience in implementing community forestry in the Terai, unlike in the hills where we tried different concepts as early as 1970s. This may be the precise reason why the new forest policy (HMG, 1989) does not speak of any provision of handing over community forests in the Terai. It is only the Forest act (HMG, 1993) which had opened the avenue for the forest handover in this region of the country (Baral et al 1998, Baral, 1998). Also, the donor supported projects which are so involved in developing community forestry in the hills since early 1970s are hardly animated to do a similar venture in the Terai. The only major welcome exceptions are the GTZ supported Churia Hills Project in the east and the USAID supported EAFEA project in the west which have quite recently embarked on working in the Terai condition. While the concerned donors might have their own constraints that might restrict them from supporting a community forestry project in the Terai. But, one of the apparent reasons for them not to embark on this activity could be the intricate problems underlying in the Terai community forestry which is difficult to solve.

Having said that, the authors do not want to suggest that the community forestry in the Terai is conceptually wrong. It is right indeed. But care must be taken to protect the traditional use right of those in the region who depend on forest for meeting their subsistence needs. However, we must make sure that the use rights of a group of HHs must not be affected while we try to show our benevolence by allowing one particular community to take a control of large tract of forest land. Neither, it is ethical to handover forest to a group by considering equity as a secondary issue rather than a primary one. Definitely our purpose is not to favour those

\section{Baral \& Subedi}

who are already more advantaged in the existing class system.

The danger to Nepal's community forestry seems not related to the government's hesitation to handover community forests in the Terai as seen by Shrestha (1999), but could be clearly connected to the lack of proper home work before speedy handover. It seems more logical to criticise the government's move for not checking the hasty handover rather than to criticise its move for a delayed handover, as Gilmour and Fisher (1989) have also opined that community forestry handover is essentially a social process which requires a lot of consciously made field efforts. Shrestha (1999) has also shown his concern over the recent amendment made in the forest act where the DFOs have been authorised to take action against the irregularities carried out by the executives. His logic that each members of the FUG is strong enough to counter balance the elite has not been evident in the present study. Elite tend to manipulate the situation in their favour. The question that who will look after such cases has still remained unsolved. While Shrestha's scepticism over the ability of the DFO to form a suitable intervener cannot be denied, he has failed to provide a more viable alternative to minimise irregularities done by the elite.

It is of course, right to point out that a delayed handover may result into a more extensive harvesting through the implementation of government's Operational Forest Management plan (OFMP). The country which still lacks scientific forest management is keen to start it at least in some parts of the productive forest of the Terai and, that a number of mature trees might have to be harvested during the implementation of OFMP. But it may be pointed out that implementation of OFMP does not affect community forestry process as a careless handover does. The OFMP enables scientific management (at least in theory) and thereby generating revenue for the country as a whole. On the other hand, a prompt handover in a race to overtake the OFMP implementation will result into transferring the control to an illegitimate authority causing infringement of traditional use rights and equity related problems both inside and the outside the forest user groups. Let us not be tempted to theorise that government control is always bad and that devolution of control is always good, inappropriate form of devolution will result into unintended consequences whereby the privileged groups or individuals may get an undue benefit at the cost of the poor or the under-privileged. The hue and cry made against the government's slow pace of hand over forests in the Terai could be a voice of those who intend to make undue profit out 


\section{Baral \& Subedi}

of the state's production forest. Attempt to rectify the problem in the handed over sites is neither easy nor philosophically consistent (Baral, 1999). Government may decide to handover any forest to the community though a new decree. Nepal's government has demonstrated its supportive attitude towards devolution throughout the history of community forestry development (see Gilmour and Fisher 1989; Baral 1999). On the other hand once the forests are handed over as community forestsm we as an outsiders ae not likely to rectify the problem situation in such a straight forward way. Once this is done, an endeavour to rectify the problem situation will take the form of 'interfering in the busigness of others'.

There are a number of issues. Whether to start a scientific management plan is the one very important. While such plan is urgently needed, our attempt to embark on it through OFMP completed from one slot survey is not likely to address the basic aspiration of the local communities. So the real issue is to find a way whereby scientific forest management plan can be implemented without affecting the local communities' aspiration.

The other important issues are ensuring use right of genuine users; ensuring equity within the members of the recognised community forestry groups; ensuring community forestry's contribution to the national treasury without affecting local enthusiams for participation, etc. Research on such important topics are underway and will be published later.

\section{References}

Baral, J. C. 1999. Government Intervention and Local Process in Community Forestry in the Hills of Nepal. Ph. D. Thesis (draft), The University of Western Sydney, Hawkesbury, N.S.W., Australia.
Banko Janakari, Vol. 9, No. 2

Baral, J. C., Paudyal, B. R., Kafle, R., Lamsal, P., K.C. Arjun, Adhikari, B. R. and Paudyal, A. R. 1997. An Internal Report on the Terai Community forest (submitted of the Depertment of Forest, Nepal)

Baral, S. R. 1998, Where is our Terai Community Forestry? Banko Janakari, 8 (2): 47-48.

Fisher, R. J., Singh, H. B., Pandey, D. R. and Lang, H. 1989. The Management of Forest Resources in Rural Development: A Case Study of Sindhu Palchok and Kabhre Palanchok Districts of Nepal.

Gilmour, D. A. and Fisher, R. J. 1991. Villagers, Forests and Foresters - The Philosophy, Process and Practice of Community Forestry in Nepal, Sahayogi Press, Kathmandu.

Gronow, J. and Shrestha, N. K. 1990. From policing to participation: reorientation of Forest Department field staff in Nepal. Research Report Series No 11, PIMG Ministry of Agriculture Winrock International, Kathmandu.

HMG. 1995. Ministry of Forest and Soil Conservation 2052 (1995), Forest Act 2049 (1993) and Forest Rules 2051

Kathmandu.

(1995),

HMG. 1989 (a). Master Plan for the Forestry Sector Nepal-Revised Forestry Sector Policy. Ministry of Forest and Environment, Kathmandu.

Shreshtha, N. K. 1999. Community Forestry in Nepal in danger. Forests, trees and People, Newsletter, No. 38: 33-34. 